ROLA „KARTY EWIDENCJI OBIEKTU NIERUCHOMEGO” W SYSTEMIE OCHRONY KONSERWATORSKIEJ DZIEDZICTWA ARCHITEKTONICZNEG0 2 P0ŁOWY XX WIEKU

The role of the "Records card of immovable propertis" in the protection and conservation of architectural heritage $2 n d$ half of the 20th century

\title{
Małgorzata Włodarczyk*
}

SUMMARY: „Record cards of immovable properties" may be used for holding information about specific assets. This tool is of utmost importance for protecting and preserving architectural heritage assets built after the second World War in the second half of the 20th century. It allows for recognising a property in advance, defining the scope of protection (whether the entire property should be protected or only its particular elements), and specifying types of works which can be carried out to the property in question. This tool turns out to be particularly important in the event of changing ownership, carrying out renovation works or any other works pertaining to redevelopment, development, adaptation, etc. Additionally, it may be used for developing historic preservation guidelines for architectural designs and the areas they affect and, at the same time, preserving their initial form. Moreover, the tool in question allows historic preservation services to carry out such works

\section{Ochrona dziedzictwa architektonicznego}

jest jednym z głównych zadań planowania miast

i zagospodarowania przestrzennego kraju. (...)

powinna uwzględnić wymogi ochrony dziedzictwa

architektonicznego i nie traktować go dłużej w sposób wyrywkowy (..... ${ }^{1}$ to historic monuments and sites that will not only respect their cultural values but also ,give them a new lease of life." Furthermore, it may be used not only in scientific or academic works but also in works aimed at general public. In the current body of law, there are two types of „record cards of immovable properties." The first one contains information on assets listed in the national register of historic monuments and sites. The second one provides data on assets not listed in this register - in this case, specific merit-related and graphical information is required. Its broader use by historic preservation service may result in increased effectiveness in preserving architectural heritage of the second half of the 20th century.

KEY WORDS: Record cards of immovable properties, historic preservation, architecture of the second half of the 20th century, contemporary cultural properties.
Obowiązujący
system
dbałości
konserwatorskiej
o dziedzictwo kulturowe regulowany jest m.in. przepisami ustawy o ochronie zabytków i opiece nad zabytkami² oraz ustawy o planowaniu i zagospodarowaniu

\footnotetext{
* PhD Arch. Małgorzata Włodarczyk, Władarczyk + Włodarczyk Architects Author’s Studio

1 Deklaracja Amsterdamska, Amsterdam 1975, [za:] Vademecum konserwatora zabytków, red. Bogusław Szmygin, Warszawa 2015, s. 214.

2 Ustawa z dnia 23 lipca 2003 r. o ochronie zabytków i opiece nad zabytkami (Dz. U. z 2014 r. poz. 1446, z późn. zm.) - stan na dzień 13.11.2015 r.
} 
przestrzennym $^{3}$ oraz towarzyszącymi im rozporządzeniami ${ }^{4}$. Ważną rolę $\mathrm{w}$ zachowaniu tego dziedzictwa, w tym spuścizny architektonicznej i kultury materialnej z 2 połowy XX wieku, może spełniać aktywniejsze wykorzystanie instytucji ewidencji zabytków nieruchomych oparte na „Karcie ewidencji obiektu nieruchomego”. W szczególności znaczenie „Karty ewidencji (...)” uwidacznia się, gdy dochodzi do zmiany właściciela nieruchomości, potrzeby jej remontu czy działań związanych z przebudową, rozbudową, adaptacją i innymi, w rozumieniu Prawa budowlanego ${ }^{5}$.

W powszechnej opinii uważa się, że wpis do rejestru zabytków zabezpiecza budynek lub budowlę przed niewłaściwą ingerencją lub zniszczeniem. Niestety bywa to narzędziem niewystarczającym z uwagi na możliwość destrukcji obiektu poprzez na przykład doprowadzenie go do ruiny. Często trudnością w przeprowadzeniu wpisu do rejestru zabytków jest brak odpowiedniej dokumentacji historyczno-architektonicznej, która pozwoliłaby na udokumentowaną argumentacjęprzemawiającąza koniecznościąorazzasadnościątakiegowpisu.W szczególnościdotyczytodziedzictwaarchitektonicznego po 1945 roku. Należy jednak zauważyć, że wraz ze wzrostem świadomości społecznej i działaniami tzw. oddolnych inicjatyw poważnej zmianie uległo również spojrzenie środowiska konserwatorskiego na dziedzictwo architektoniczne tego okresu. Ciągle jednak nie zawsze jednak dotyczy to związanego $\mathrm{z}$ architekturą i urbanistyką dziedzictwa plastycznego takiego jak rzeźba, malarstwo, mozaiki i detal. W sytuacji braku wpisu obiektu do rejestru zabytków w gestii wojewódzkiego Konserwatora Zabytków funkcjonują wspomniane już inne narzędzia ich ochrony.

Wpis do gminnej lub wojewódzkiej ewidencji zabytków jest od 2011 roku jednym z możliwych, a nie wymienionych literalnie w ustawie, narzędzi które służą ochronie zabytków wpisanych do rejestru i tych nie wpisanych do rejestru. Wykorzystanie możliwości wypływających z obowiązujących, być może niedoskonałych, ale już funkcjonujących metod działania pozwala miejskiemu-gminnemu i wojewódzkiemu Konserwatorowi Zabytków na skuteczną ochronę dziedzictwa architektonicznego, architektury po II wojnie światowej. Obowiązek prowadzenia ewidencji obiektów podlegających ochronie jest jednym z zadań konserwatorskich związanych z działalnością na poziomie terenowym, tj. na poziomie województwa i na poziomie lokalnym ${ }^{6}$. Istotną rolę mają tu do spełnienia „Karty ewidencji (...)”. Pozwalają one na pełniejsze uzasadnienie ujęcia poszczególnych realizacji, w tym dóbr architektury współczesnej, w zasobie gminnej lub wojewódzkiej ewidencji zabytków. Brak takich uzasadnień bywa często powodem odwołań od decyzji stron niezadowolonych z takich wpisów. Ewidencja zabytków, aby spełniała swoją nie tylko prewencyjną, ale i kulturową rolę, powinna być zatem wzbogacona każdorazowo o indywidualną "Kartę ewidencyjną obiektu nieruchomego”,

Ustawa O planowaniu i zagospodarowaniu przestrzennym z dnia 05 lutego 2015 r. (Dz. U. 2015 Nr 199).

4 Rozporządzenie Ministra Kultury i Dziedzictwa Narodowego z dnia 26 maja 2011 r. w sprawie prowadzenia rejestru zabytków, krajowej, wojewódzkiej i gminnej ewidencji zabytków oraz krajowego wykazu zabytków skradzionych lub wywiezionych za granicę niezgodnie z prawem (Dz. U. Nr 113, poz. 661) oraz Rozporządzenie Ministra Kultury i Dziedzictwa Narodowego z dnia 14 października 2015 r. w sprawie prowadzenia prac konserwatorskich, prac restauratorskich, robót budowlanych, badań konserwatorskich, badań architektonicznych i innych działań przy zabytku wpisanym do rejestru zabytków oraz badań archeologicznych i poszukiwań zabytków (Dz. U. poz. 1789).

5 Ustawa Prawo budowlane z dnia 07 lipca 1994 r. (Dz. U. Nr 89, poz. 414, z póżn. zm.).

6 Narodowy Instytut Dziedzictwa (NID) w ramach podstawowych zadań gromadzi i zarządza zasobem krajowej ewidencji zabytków. Więcej: http://www.nid.pl/pl/Informacje_ogolne/Zabytki_w_Polsce/ Ewidencja_zabytkow/. 
opracowywaną dla danej realizacji architektonicznej ${ }^{7}$. Również dla takiej, która nie jest wpisana do rejestru zabytków, ale która $\mathrm{z}$ uwagi na swoje wartości dla dziedzictwa kulturowego powinna być przedmiotem zainteresowania służb konserwatorskich.

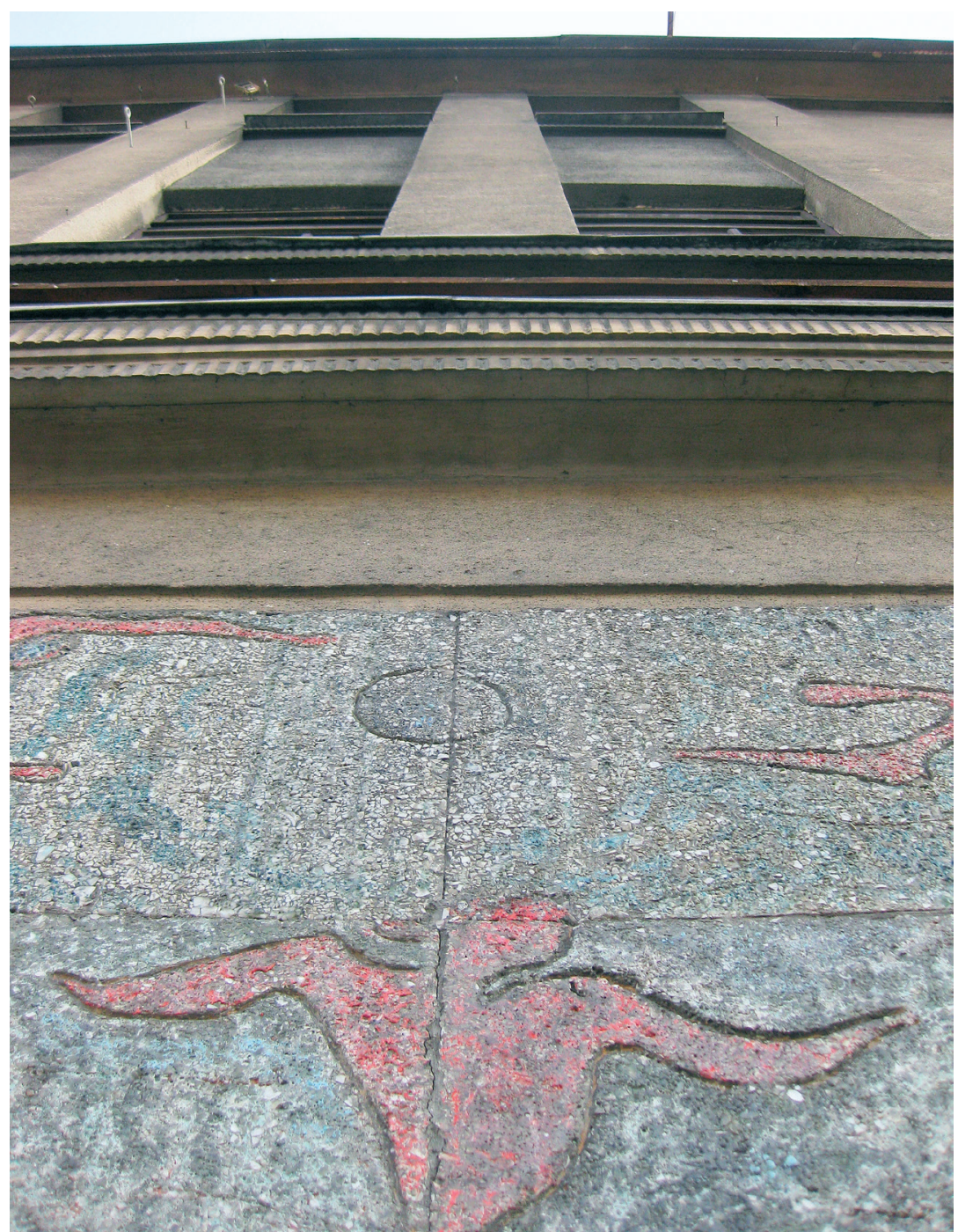

1. Fragment elewacji frontowej Klubu Sportowego „Korona”, ul. Kalwaryjska 9, Kraków. Przykład realizacji dekoracji plastycznej w nowatorskiej i autorskiej technice piropiktury.

Projektant budynku: Jan Krug, Marona, Andrzej Bahr

Projekt: 1952-1958; Realizacja: 1956-1960; Piropiktura na elewacji: Helena i Roman Husarscy Foto: Marcin Włodarczyk, 2014

7 Wzory kart określone są w załączniku do rozporządzenia Ministra Kultury z dnia 26 maja 2011 r., w sprawie prowadzenia rejestru zabytków, krajowej, wojewódzkiej i gminnej ewidencji zabytków oraz krajowego wykazu zabytków skradzionych lub wywiezionych za granicę niezgodnie z prawem (Dz. U. Nr 113 z 2011r., poz. 661.). 
„Karta ewidencyjna (...)” obiektu, rozróżniana jest w obecnym unormowaniu na opisującą obiekty objęte wpisem do rejestru zabytków i obiekty nie wpisane do rejestru, co związane jest z jej zawartością. Jako narzędzie, które ma być pomocne w działaniu wojewódzkiego i gminnego Konserwatora Zabytków, powinna być raczej jednolita, bez powyższego rozróżnienia co do zawartości obszerności, tj. w formie i zakresie takim samym dla wszystkich obiektów. Przeprowadzana kwerenda bywa często jedyną formą ich „zachowania” zabytków i architektury powstałej po II wojnie światowej, w związku z tym, że stanowią one przedmiot obrotu inwestycyjnego. Skromniejsza wersja takiej Karty pozbawia opis budynku lub budowli uszczegółowień i szerszych odniesień. Tym samym ogranicza wiedzę, jaką powinny dysponować osoby oraz instytucje zajmujące się ochrona i opieką nad zabytkami oraz dobrami kultury współczesnej, a także projektanci i naukowcy wykonujący prace projektowe i badawcze.

Informacje zawarte w prawidłowo i wieloaspektowo opracowanej „Karcie ewidencji (...)” wskazują również jakim materiałem źródłowym i historycznymi może dysponować służba konserwatorska na etapie zaleceń przy opisie obiektu w ramach wpisu do rejestru zabytków lub przy wydawaniu opinii i decyzji w ramach postępowań administracyjnych. W szczególności, w przypadku budynków, zabytków architektury współczesnej, nie wpisanych do rejestru ale ujętych w gminnej lub wojewódzkiej ewidencji zabytków, czy też chronionych planem miejscowym, ${ }^{8}$ stanowiących część dziedzictwa kulturowego. Zawartość „Karty ewidencji (...)” może byćtakże użyteczna w opracowywaniu wytycznych konserwatorskich dla projektów architektonicznych, a także w odniesieniu do samego obiektu i strefy jego oddziaływania. Podobnie może ona także służyć jako materiał dla publikacji naukowych lub popularyzatorskich.

Wsparciem dla służb konserwatorskich są oczywiście materiały archiwalne oraz opinie specjalistyczne opracowywane i gromadzone przez Narodowy Instytut Dziedzictwa. Czas konieczny na ich przygotowanie przedłuża jednak niejednokrotnie czas procedowania poszczególnych decyzji i podejmowania działań. Natomiast „Karta ewidencji (...)” pozwalać może na pewne wyprzedzające rozpoznanie obiektu, a także na określenie jaki powinien być zakres ochrony, czego konkretnie ma dotyczyć, tj. całości czy poszczególnych elementów oraz na jaki zakres ingerencji można zezwolić. Jest to szczególnie istotne w odniesieniu do dóbr kultury architektury współczesnej, z 2 połowy XX wieku, będących częścią naszego dziedzictwa kulturowego. Daje to sposobność do takich działań służb

Rozróżnienie pojęć: zabytek i dziedzictwo kulturowe zawarte jest w przywołanych na wstepie ustawach i dokumentach podlegających implementacji do naszego prawodawstwa. Obejmuje te zagadnienia w szczególności: Ustawa z dnia 23 lipca 2003 roku o ochronie zabytków i opiece nad zabytkami (Dz.U. 2003, Nr 162, poz. 1568 ze zmianami); Rozporządzenie Ministra Kultury i Dziedzictwa Narodowego z dnia 26 maja 2011 r. w sprawie prowadzenia rejestru zabytków, krajowej, wojewódzkiej i gminnej ewidencji zabytków oraz krajowego wykazu zabytków skradzionych lub wywiezionych za granicę niezgodnie z prawem (Dz.U.2011, nr 113, poz. 661); Rozporządzenie Ministra Kultury i Dziedzictwa Narodowego z dnia 14 października 2015 r. w sprawie prowadzenia prac konserwatorskich, prac restauratorskich, robót budowlanych, badań konserwatorskich, badań architektonicznych i innych działań przy zabytku wpisanym do rejestru zabytków oraz badań archeologicznych i poszukiwań zabytków (Dz. U. poz. 1789). A także przepisy Ustawy z dnia 7 lipca 1994 r. Prawo budowlane (Dz.U. 1994 nr 89 poz. 414 ze zmianami) oraz Ustawy z dnia 27 marca 2003 r. o planowaniu i zagospodarowaniu przestrzennym (Dz.U. 2003 Nr 80 poz. 717 ze zmianami) Ewidencja zabytków jest podstawą do sporządzania programów opieki nad zabytkami przez województwa, powiaty i gminy (art. 21. Ustawy o ochronie zabytków i opieki nad zabytkami). Szerzej o znaczeniu i prowadzeniu ewidencji na stronie Narodowego Instytutu Dziedzictwa: http://www.nid.pl/pl/Informacje_ogolne/Zabytki_w_Polsce/Ewidencja_zabytkow/ 
konserwatorskich, aby przy poszanowaniu budynku umożliwić jego adaptację i przystosowanie do nowych uwarunkowań, czyli pozwolić na jego dalsze, „nowe życie”. Zapewniając przy tym możliwie dalekie utrzymanie jego pierwotnego wyrazu.

W kontekście powyższych rozważań i w nawiązaniu do powracających wśrodowisku konserwatorskim sugestii powrotu do kategoryzacji zabytków, jej zastosowanie w odniesieniu do architektury 2 połowy XX wieku wydaje sie trudne. Doświadczenia minionego okresu też są negatywne, co skutkowało odejściem od tak zinstytucjonalizowanej formy podejścia do obiektów architektonicznych. „Karta ewidencji (...)" może być jednak pomocna przy waloryzacji i wartościowaniu budynków, w szczególności w związku $\mathrm{z}$ ich kwalifikacją co do sposobu i zakresu ochrony, w tym przy procedowaniu planów miejscowych, wpisie do ewidencji czy decyzji o wpisie do rejestru zabytków.

Obowiązujące uregulowania, związane ze zmianą ustawy „O ochronie zabytków i opiece nad zabytkami”, stwarzająwiększą,jaksięwydaje,gwarancjęotwartościidyskusjispołecznejorazmożliwości indywidualnych decyzji poszczególnych wojewódzkich i gminnych konserwatorów zabytków, bez konieczności dostosowania do politycznych działań. Narodowy program „Ochrona zabytków i dziedzictwa kulturowego stanowi” część Narodowej Strategii Ochrony Kultury i został rozszerzony o „Uzupełnienie Narodowej Strategii Ochrony Kultury na lata 2004-2020” przyjętym w 2005 roku. „Narodowa strategia (...)” wskazuje cele polityki państwa w zakresie kultury, natomiast „Narodowy program (...) realizuje założenia zawarte $\mathrm{w}$ „Narodowej strategii (...). W odniesieniu do służb konserwatorskich zapisano w niej, m.in. konieczność poprawienia ich funkcjonowania, a także potrzebę upowszechniania edukacji społecznej na rzecz dziedzictwa. Uchwalono także „Narodowy program ochrony zabytków i dziedzictwa kulturowego", przyjęty w 2014 roku. Podczas konsultacji tego dokumentu uwagi dotyczyły również podporządkowania wojewódzkich konserwatorów zabytków ministrowi właściwemu. Ta zmiana modelu podległości administracyjnej, wprowadzona ustawą $^{10} \mathrm{z}$ kwietnia 2016 roku wiąże się $\mathrm{z}$ odejściem od idei służby zespolonej $\mathrm{w}$ administracji wojewódzkiej (i podlegania wojewodom). Nastąpił powrót zwierzchności Generalnego Konserwatora nad wojewódzkimi konserwatorami zabytków. Jest to szczególnie istotne w przypadku obiektów architektonicznych oraz ich uwarunkowań przestrzennych, historycznych i mentalnych, różnych w poszczególnych częściach kraju.

„Karta ewidencji obiektu nieruchomego” mogłaby również zostać rozszerzona o cyfrowy zapis dokumentacji, w tym $\mathrm{z}$ wykorzystaniem współczesnych technik trójwymiarowych. W przypadku destrukcji budynku lub budowli byłaby to wtedy forma jego zachowania dla przyszłych pokoleń. W obecnym czasie technologii druku w 3D całych materialnych obiektów pozwoliłoby to na ich ewentualne odtworzenie.

Włączenie „Kart ewidencji (...)” w aktywny system dokumentacji, w tym w szersze społeczne uczestnictwo w gromadzeniu danych i wykonywaniu inwentaryzacji fotograficznej wzmocniłoby relacje ze służbami konserwatorskimi. Takie wsparcie systemu ochrony zabytków i opieki nad zabytkami być może pozwoliłoby na skuteczniejsze działania służb konserwatorskich, również wobec dziedzictwa architektonicznego 2 połowy XX wieku.

Uchwała nr 125/2014 z dnia 24 czerwca 2014 roku w sprawie „Krajowego programu ochrony zabyttów i opiece nad zabytkami”.

10 Projekt z dnia 1 kwietnia 2016 roku "Ustawy o zmianie ustawy o ochronie zabytków i opiece nad zabytkami oraz o zmianie ustawy o wojewodzie i administracji rządowej w województwie”; http://www.konsultacje.gov. $\mathrm{pl} /$ node/4045. 
